\title{
ANALYTICAL METHOD DEVELOPMENT AND VALIDATION FOR THE SIMULTANEOUS ESTIMATION OF EMTRICITABINE AND TENOFOVIR BY REVERSED-PHASE HIGH PERFORMANCE LIQUID CHROMATOGRAPHY IN BULK AND TABLET DOSAGE FORMS
}

\author{
SUFIYAN AHMAD ${ }^{1 *}$, Md. RAGEEB Md. USMAN ${ }^{2}$
}

${ }^{1}$ Department of Quality Assurance, Gangamai College of Pharmacy, Nagaon, Dhule, Maharashtra, India. ${ }^{2}$ Department of Pharmacognosy, Smt. S. S. Patil Chopda College of Pharmacy, Chopda, Maharashtra, India. Email: sufimpharm@rediffmail.com

Received: 05 June 2017, Revised and Accepted: 11 July 2017

\section{ABSTRACT}

Objective: A simple rapid, accurate, precise, and reproducible validated reversed-phase high performance liquid chromatography method was developed for the determination of emtricitabine (EMB) and tenofovir (TEN) in bulk and tablet dosage forms.

Methods: The quantification was carried out using symmetry Premsil $\mathrm{C}_{18}(250 \mathrm{~mm} \times 4.6 \mathrm{~mm}, 5 \mu \mathrm{m})$ Younglin (S.K.) gradient way using mobile phase comprising of methanol:water $(70: 30 \mathrm{v} / \mathrm{v}) \mathrm{pH} 3$ and a detection wavelength of $273 \mathrm{~nm}$, and injection volume of $20 \mu \mathrm{L}$, with a flow rate of $1 \mathrm{ml} / \mathrm{minutes}$.

Results: In the developed method, the retention time of EMB and TEN were found to be 3.1667 minutes and 7.5000 minutes. The developed method was validated according to the International Conference on Harmonization (ICH) guidelines.

Conclusion: The linearity, precision, range, robustness was within the limits as specified by the ICH guidelines. Hence, the method was found to be simple, accurate, precise, economic, and reproducible. Hence, it is worthwhile that the proposed methods can be successfully utilized for the routine quality control analysis EMB and TEN in bulk drug as well as in formulations.

Keywords: Emtricitabine and tenofovir, Method development, Validation, Simultaneous estimation, High performance liquid chromatography.

(C) 2017 The Authors. Published by Innovare Academic Sciences Pvt Ltd. This is an open access article under the CC BY license (http://creativecommons. org/licenses/by/4. 0/) DOI: http://dx.doi.org/10.22159/ajpcr.2017.v10i11.20477

\section{INTRODUCTION}

Emtricitabine (EMB) and tenofovir (TEN) are antiretroviral drugs used for the treatment of Human Immune Syndrome [1]. Forstavir - EM is the combination of the two drugs containing $150 \mathrm{mg}$ of EMB and $300 \mathrm{mg}$ of TEN. EMB is chemically 4-Amino-5-fluoro-1-[2-(hydroxyl methyl)-1, 3-oxathiolan-5-yl]-pyrimidin-2-one [2,3]. It is a nucleoside reverse transcriptase inhibitor (Fig. 1). Chemically TEN is 1-(6-aminopurin9-yl)-prapan-2-yl-oxymethylphosphonic acid [3,4]. It is a nucleotide analogue reverse transcriptase inhibitor (Fig. 2). Extensive literature survey revealed that only liquid chromatography mass spectroscopy (LCMS/MS) and reversed-phase high performance liquid chromatography (RP-HPLC) [5,6] methods for the determination of EMB and TEN in human plasma, RP-HPLC [7] for determination of TEN in plasma, LC/MS/ MS for determination of plasma TEN concentrations [8], LC-MS method for determination of plasma TEN concentrations [9], and HPLC with fluorimetric detection for determination of EMB in human plasma [10] have been reported so far. There is no evidence of determination of the drug combination by HPLC. Thus, this study is to develop simple, precise, and accurate HPLC methods for the quantification of EMB and TEN in combined dosage form.

\section{METHODS}

\section{Reagents and materials}

The analysis of the drug was performed on Youngline (S.K.) gradient system ultraviolet (UV) detector. Equipped with Reverse Phase (premsil) c18 column $(4.6 \mathrm{~mm} \times 250 \mathrm{~mm} ; 5 \mu \mathrm{m})$, a SP930D pump, a $20 \mu \mathrm{l}$ injection loop and UV730D Absorbance detector and running autochro-3000 software.

EMB and TEN in the form of gift samples were kindly supplied by R. S. I. T. C, Jalgaon. AR grade methanol used for HPLC method and methanol: Water $(0.1 \%$ orthophosphoric acid [OPA]), prepared in solvent double distilled water was used as solvent throughout the study. A combination of EMB $(20 \mathrm{mg})$ and TEN $(30 \mathrm{mg})$ in tablet formulation was procured from local pharmacy (Travin-EM, Emcure Pvt., Ltd).

\section{Chromatographic conditions}

Column C18 (250 mm $\times 4.6 \mathrm{~mm}$ ); particle size packing $5 \mu \mathrm{m}$; detection wavelength $271 \mathrm{~nm}$; flow rate $0.5 \mathrm{ml} /$ minutes; temperature ambient; sample size $20 \mu \mathrm{l}$; mobile phase acetonitrile: Water $(0.05 \%$ OPA with pH 3) $(50+50 \% \mathrm{v} / \mathrm{v})$; run time 10 minutes.

\section{Preparation of standard stock solution}

Preparation of standard EMB solution: (Stock I)

From the freshly prepared standard stock solution $(1000 \mu \mathrm{g} / \mathrm{ml}), 0.1 \mathrm{ml}$ stock solution was pipette out in $10 \mathrm{ml}$ of volumetric flask and volume was made up to $10 \mathrm{ml}$ with mobile phase to get final concentration of $10 \mu \mathrm{g} / \mathrm{ml}$ (Fig. 3).

\section{Preparation of standard TEN solution: (Stock II)}

From the freshly prepared standard stock solution $(1000 \mu \mathrm{g} / \mathrm{ml}), 0.1 \mathrm{ml}$ stock solution was pipette out in $10 \mathrm{ml}$ of volumetric flask and volume was made up to $10 \mathrm{ml}$ with mobile phase to get final concentration $10 \mu \mathrm{g} / \mathrm{ml}$ (Fig. 4).

\section{Preparation of standard EMB and TEN solution: (Stock III)}

From the freshly prepared standard stock solution $(1000 \mu \mathrm{g} / \mathrm{ml}), 0.1 \mathrm{ml}$ stock solution was pipette out in $10 \mathrm{ml}$ of volumetric flask and volume was made up to $10 \mathrm{ml}$ with mobile phase to get final concentration $10 \mu \mathrm{g} / \mathrm{ml}$. In the standard mixture of EMB and TEN theoretical plates (TP) were found above 2000, i.e., for EMB 4085.3 and TEN 11229.0 at minimum retention time (RT) 3.1667 and 7.500, respectively (Fig. 5 and Table 1). 


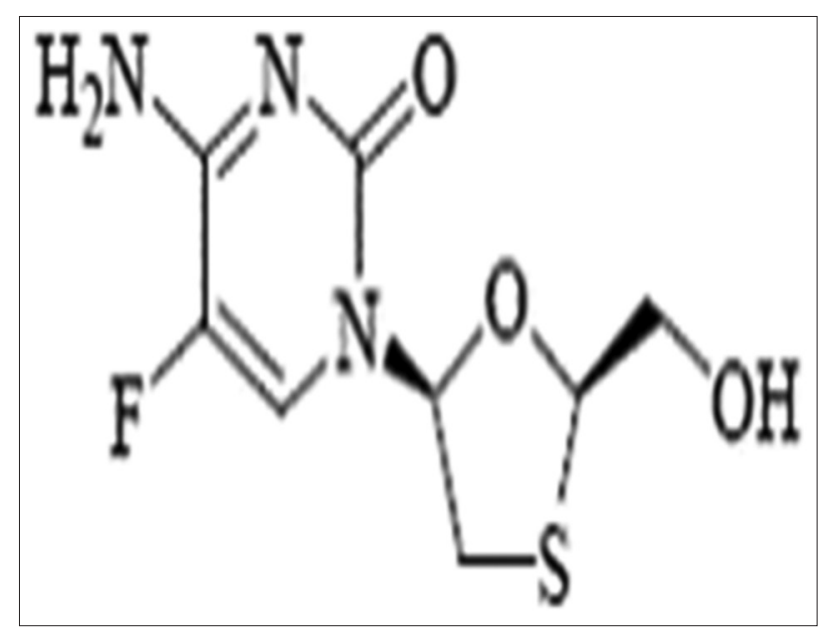

Fig. 1: Structure of emtricitabine

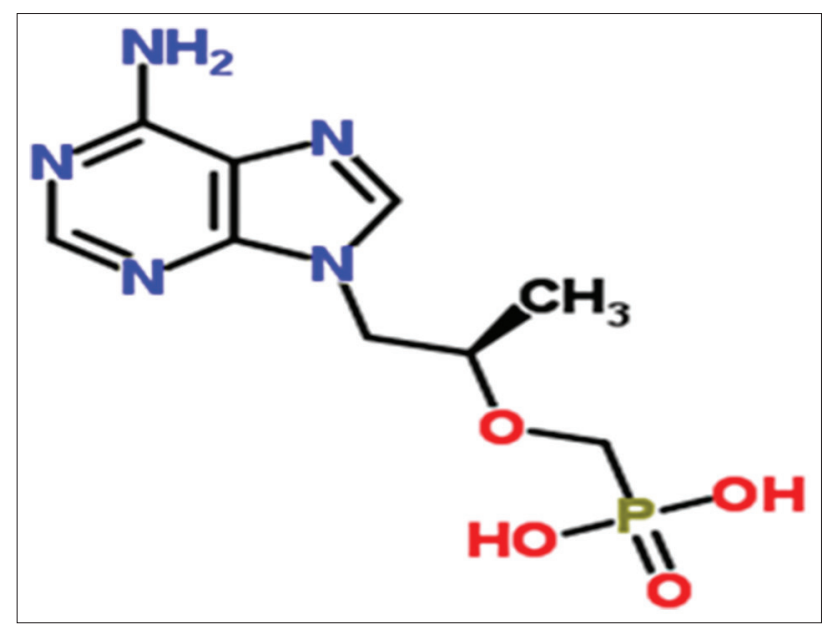

Fig. 2: Structure of tenofovir

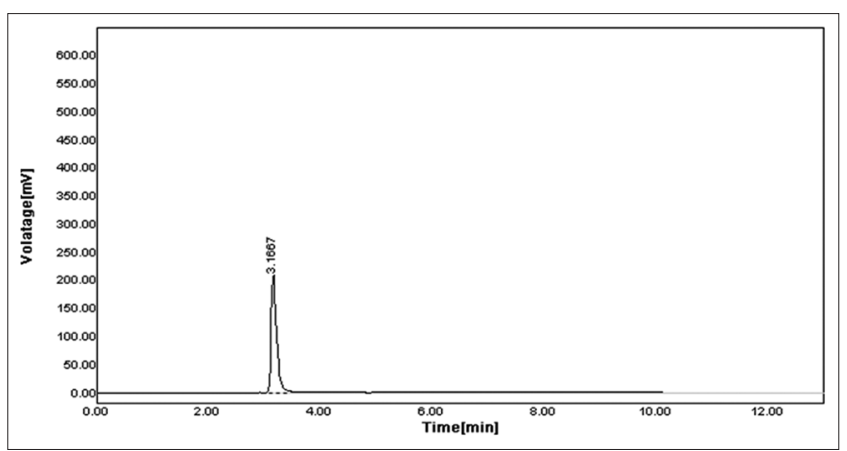

Fig. 3: Chromatogram of standard emtricitabine

\section{Method development and validation}

Working standard of concentrations was prepared by taking aliquots of standard solution and diluted to get required concentration for calibration plot and which was injected [11,12].

\section{Assay preparation for commercial formulation}

Weigh 20 EMB and TEN combination tablets weigh $14.98 \mathrm{~g}$ and calculated the average weight of powder $0.749 \mathrm{~g}$ accurately weigh and transfer the sample equivalent to $49.93 \mathrm{mg}$ EMB and TEN into $10 \mathrm{ml}$ volumetric flask. Add about $10 \mathrm{ml}$ methanol of diluents and sonicate to dissolve it completely and make volume up to the mark with diluents. Mix well and filter through $0.45 \mu \mathrm{m}$ filter. Further pipette $0.1 \mathrm{ml}$ of the

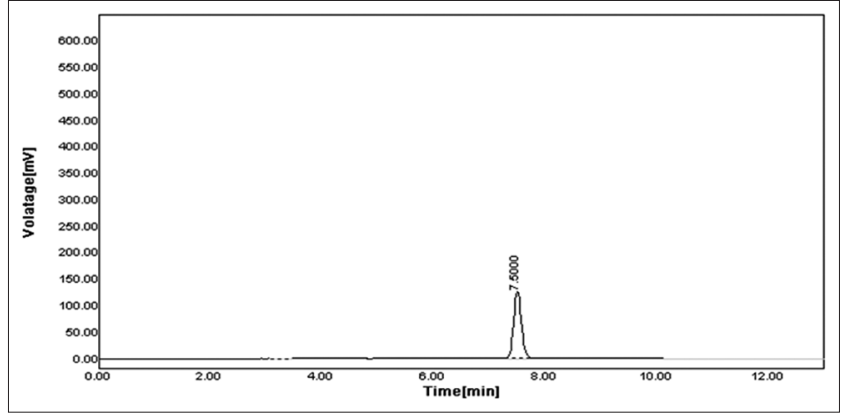

Fig. 4: Chromatogram of standard tenofovir

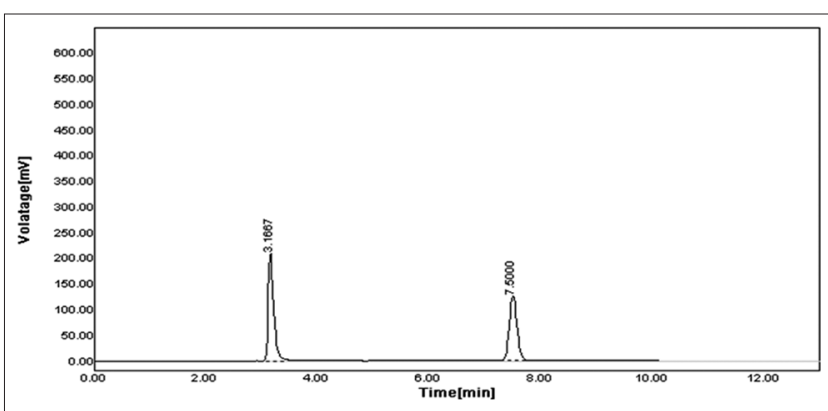

Fig. 5: Chromatogram of standard combination of emtricitabine and tenofovir

Table 1: Details of chromatogram of standard combination containing EMB and TEN

\begin{tabular}{llllll}
\hline $\begin{array}{l}\text { RT } \\
\text { (minutes) }\end{array}$ & Area (mV*s) & Area (\%) & TP & TF & Resolution \\
\hline 3.1667 & 1470.3370 & 54.64 & 4085.3 & 1.3333 & 0.0000 \\
7.5000 & 1220.3994 & 45.36 & 11229.0 & 1.1667 & 15.2941 \\
& 2690.7363 & & & & \\
\hline
\end{tabular}

EMB: Emtricitabine, TEN: Tenofovir, RT: Retention time, TP: Theoretical plates, TF: Tailing factor

above stock solution into a $10 \mathrm{ml}$ volumetric flask and dilute up to the mark with diluents. $(10 \mu \mathrm{g} / \mathrm{ml})$. The simple chromatogram of test EMB and TEN shown in Fig. 6. The amounts of EMB and TEN per tablet were calculated by extrapolating the value of area from the calibration curve. Analysis procedure was repeated five times with tablet formulation. Analysis of marketed formulation was also \% Label Claim was found to be $99-101 \%$ satisfactory are concluded (Table 2).

\section{RESULTS}

\section{Linearity and range}

The data obtained in the calibration experiments when subjected to linear regression analysis showed a linear relationship between peak areas and concentrations in the range $10-50 \mu \mathrm{g} / \mathrm{ml}$ for EMB and $15-75 \mu \mathrm{g} / \mathrm{ml}$ for TEN (Tables 3 and 4 ] depict the calibration data of EMB and TEN The respective linear equation for EMB was $y=62.06 x+0.546$ and TEN equation $\mathrm{y}=47.73 \mathrm{x}+55.11$ where $\mathrm{x}$ is the concentration and $\mathrm{y}$ is area of peak. The correlation coefficient was 0.999 . The calibration curve of EMB and TEN is depicted in Figs. 7 and 8.

\section{Accuracy}

It is defined as closeness of agreement between the actual (true) value and analytical value and obtained by applying test method for a number of times. The accuracy of the methods was determined at three different concentration levels, i.e. , $80 \%, 100 \%$, and $120 \%$ (Figs. 9-11) in triplicate for each drug as per International Conference on Harmonization guidelines. From the total amount of drug found, the percentage recovery was fond in range of 99-101\% (Tables 5 and 6). 
Table 2: Analysis of marketed formulation

\begin{tabular}{llllll}
\hline Assay & Drug & Label claimed & Amount found & \% Label claim & SD \\
\hline RP-HPLC method & EMB & 10 & 9.90 & 99.0 & 101.87 \\
& TEN & 15 & 15.28 & 101.10 & 0.15 \\
& EMB & 10 & 10.11 & 0.13 & 0.27 \\
& TEN & 15 & 15.09 & 0.27 & 100.60 \\
\hline
\end{tabular}

EMB: Emtricitabine, TEN: Tenofovir, SD: Standard deviation, RSD: Relative standard deviation, RP-HPLC: Reversed-phase high performance liquid chromatographic, RT: Retention time

Table 3: Linearity data for EMB

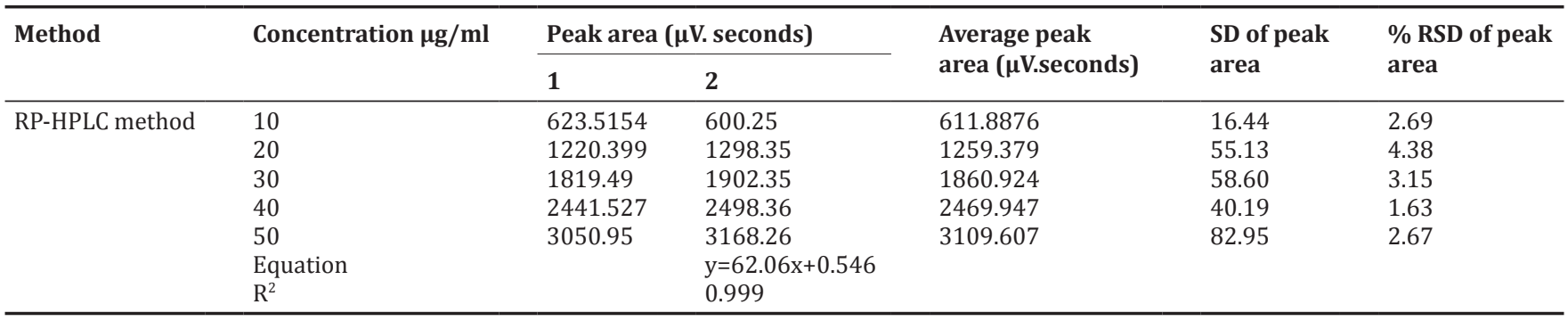

RP-HPLC: Reversed-phase high performance liquid chromatographic, RSD: Relative standard deviation, SD: Standard deviation, EMB: Emtricitabine

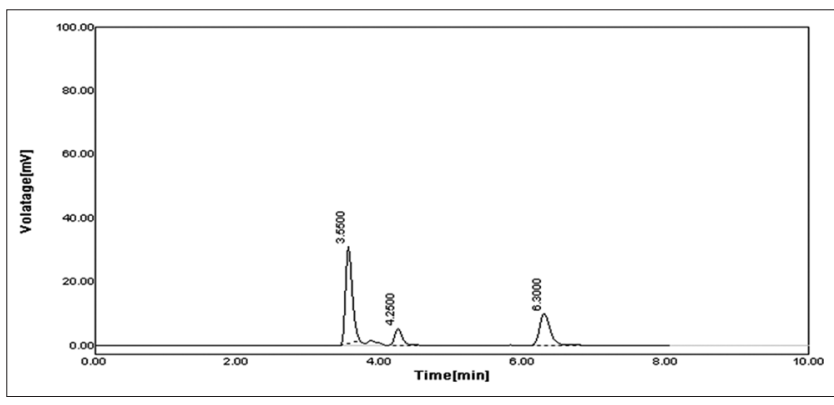

Fig. 6: Chromatogram for marketed formulation

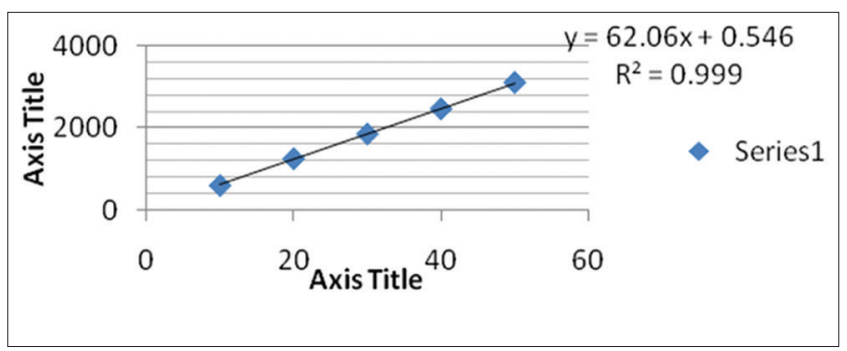

Fig. 7: Calibration curve of emtricitabine

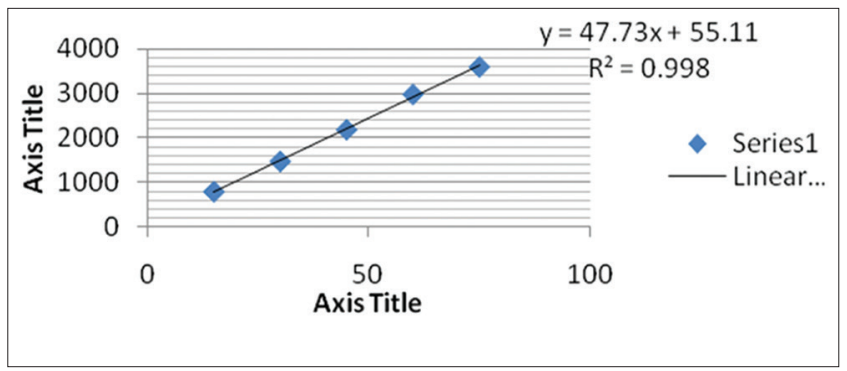

Fig. 8: Calibration curve of tenofovir

\section{Precision}

Precision was studied to find out intra- and interday variations in the test method of EMB and TEN. Intraday precision was determined by analyzing three concentration in three replicate measurements of

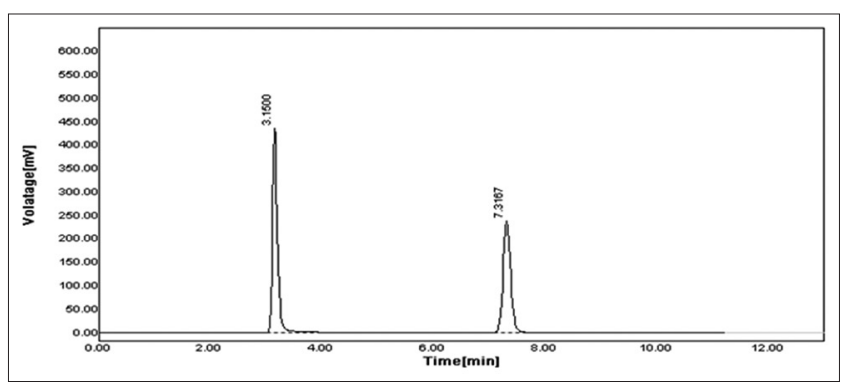

Fig. 9: Chromatogram of accuracy $80 \%$

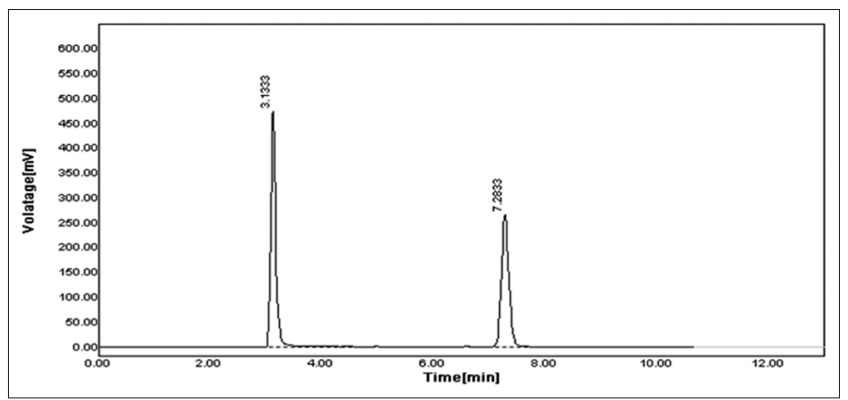

Fig. 10: Chromatogram of accuracy $100 \%$

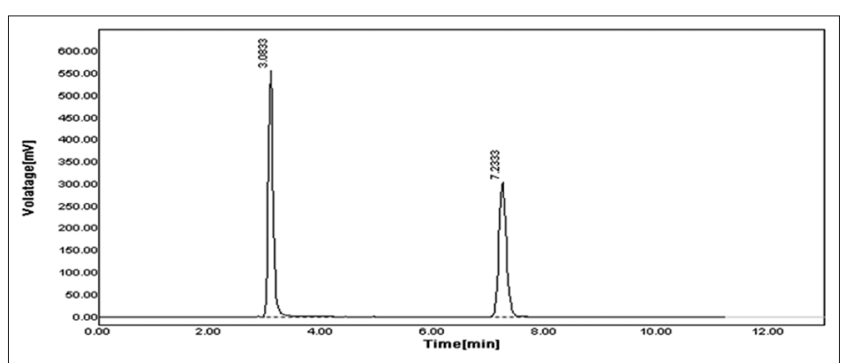

Fig. 11: Chromatogram of accuracy $120 \%$

within linearity range of drugs on three different times in the same day. Interday precision was conducted during routine operation of the system over a period of 3 consecutive days. Intra- and Interday 
Table 4: Linearity data for TEN

\begin{tabular}{|c|c|c|c|c|c|c|}
\hline \multirow[t]{2}{*}{ Method } & \multirow[t]{2}{*}{ Concentration $\mu \mathrm{g} / \mathrm{ml}$} & \multicolumn{2}{|c|}{ Peak area ( $\mu$ V.seconds) } & \multirow[t]{2}{*}{ Average peak area ( $\mu$ V.seconds) } & \multirow{2}{*}{$\begin{array}{l}\text { SD of peak } \\
\text { area }\end{array}$} & \multirow{2}{*}{$\begin{array}{l}\% \text { RSD of } \\
\text { peak area }\end{array}$} \\
\hline & & 1 & 2 & & & \\
\hline \multirow{6}{*}{ RP-HPLC method } & 15 & 775.2776 & 788.365 & 781.8213 & 9.25 & 1.18 \\
\hline & 45 & 2202.554 & 2165.296 & 2183.925 & 26.34 & 1.21 \\
\hline & 60 & 3008.865 & 2956.354 & 2982.609 & 37.13 & 1.24 \\
\hline & 75 & 3638.126 & 3568.265 & 3603.195 & 49.40 & 1.37 \\
\hline & Equation & & $y=47.73 x+55.11$ & & & \\
\hline & $\mathrm{R}^{2}$ & & 0.998 & & & \\
\hline
\end{tabular}

RP-HPLC: Reversed-phase high performance liquid chromatographic, SD: Standard deviation, RSD: Relative standard deviation, TEN: Tenofovir

Table 5: Recovery data for EMB and TEN

\begin{tabular}{|c|c|c|c|c|c|c|c|}
\hline \multirow[t]{2}{*}{ Method } & \multirow[t]{2}{*}{ Drug } & \multirow[t]{2}{*}{ Level (\%) } & \multirow[t]{2}{*}{ Amount taken $(\mu \mathrm{g} / \mathrm{ml})$} & \multirow[t]{2}{*}{ Amount added $(\mu \mathrm{g} / \mathrm{ml})$} & \multicolumn{3}{|l|}{ Mean* $*$ SD } \\
\hline & & & & & Absorbance & Amount recovered & \% Recovery \\
\hline RP-HPLC & EMB & 80 & 20 & 10 & $35.99 \pm 0.27$ & $15.99 \pm 0.27$ & $99.96 \pm 1.70$ \\
\hline \multirow{5}{*}{ method } & & 100 & 10 & 20 & $39.94 \pm 0.30$ & $20.58 \pm 0.30$ & $99.72 \pm 1.48$ \\
\hline & & 120 & 20 & 24 & $43.85 \pm 0.27$ & $23.85 \pm 0.27$ & $101.58 \pm 1.15$ \\
\hline & TEN & 80 & 30 & 24 & $54.20 \pm 0.42$ & $24.20 \pm 0.42$ & $100.8 \pm 1.75$ \\
\hline & & 100 & 30 & 30 & $60.46 \pm 0.34$ & $20.58 \pm 0.34$ & $101.5 \pm 1.74$ \\
\hline & & 120 & 30 & 36 & $66.40 \pm 0.30$ & $36.40 \pm 0.30$ & $101.5 \pm 0.84$ \\
\hline
\end{tabular}

*Mean of each 3 reading for RP-HPLC method. RP-HPLC: Reversed-phase high performance liquid chromatographic, SD: Standard deviation, EMB: Emtricitabine,

TEN: Tenofovir

Table 6: Statistical validation of recovery studies EMB and TEN

\begin{tabular}{llllll}
\hline Method & $\begin{array}{l}\text { Level of } \\
\text { recovery (\%) }\end{array}$ & Drug & $\begin{array}{l}\text { Mean \% } \\
\text { recovery }\end{array}$ & SD* & \% RSD \\
\hline RP-HPLC & 80 & EMTRI & 99.96 & 1.70 & 1.70 \\
method & \multirow{2}{*}{100} & TENO & 100.83 & 1.75 & 1.74 \\
& \multirow{2}{*}{120} & EMTRI & 99.72 & 1.48 & 1.49 \\
& & TENO & 101.53 & 1.74 & 1.12 \\
& & EMTRI & 101.58 & 1.15 & 1.93 \\
& & TENO & 101.58 & 0.84 & 0.84 \\
\hline
\end{tabular}

*Denotes average of three determinations for RP-HPLC.

RP-HPLC: Reversed-phase high performance liquid chromatographic,

SD: Standard deviation, RSD: Relative standard deviation, EMB: Emtricitabine, TEN: Tenofovir

precision studies on HPLC method for EMB and TEN which shows the high precision \% amount in between 98\% and 100\% indicates to analytical method that concluded (Table 7 and Figs. 12-14).

\section{Limit of detection (LOD) and limit of quantification (LOQ)}

LOD is the lowest amount of analyte in a sample that can be detected but not necessarily quantify under the stated experimental conditions. LOQ is the lowest concentration of analyte in a sample that can be determined with the acceptable precision and accuracy under stated experimental conditions.

\section{Robustness}

The robustness is measure of its capacity to remain unaffected by small and deliberate variations in method parameters and provides an indication of its reliability during normal usage; hence, the following are performed by slight variations in parameters. The changes were did flow rate $\left( \pm 1 \mathrm{ml} /\right.$ minute $\left.^{-1}\right), \mathrm{pH}$ of mobile phase composition $\left( \pm 1 \mathrm{ml} /\right.$ minute $\left.^{-1}\right)$, and Wavelength $\left( \pm 1 \mathrm{ml} /\right.$ minute $\left.^{-1}\right) . \%$ relative standard deviation (RSD) for peak area was calculated which should be $<2 \%$. The result is shown in Tables 8 and 9 .

\section{Repeatability}

Repeatability studies on HPLC method for EMB and TEN were found to be, the $\%$ RSD was $<2 \%$, which shows high percentage amount found in

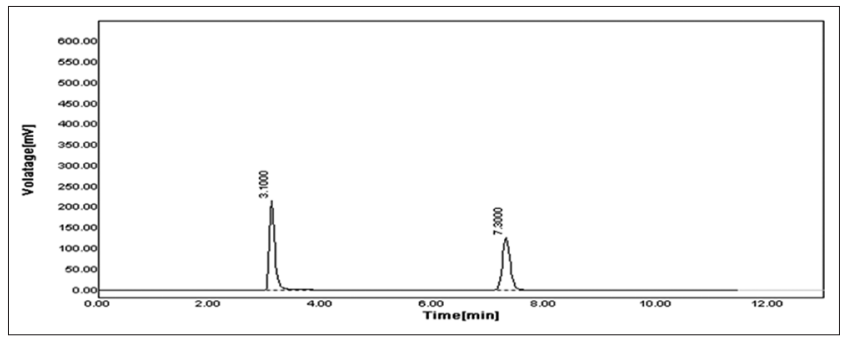

Fig. 12: Chromatogram of precision

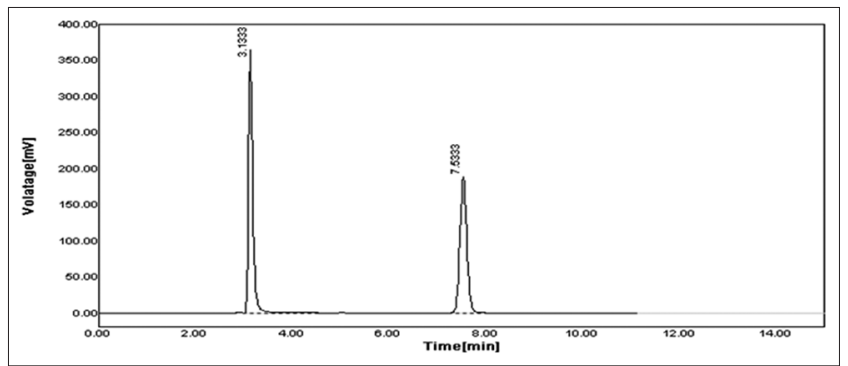

Fig. 13: Chromatogram intraday precision

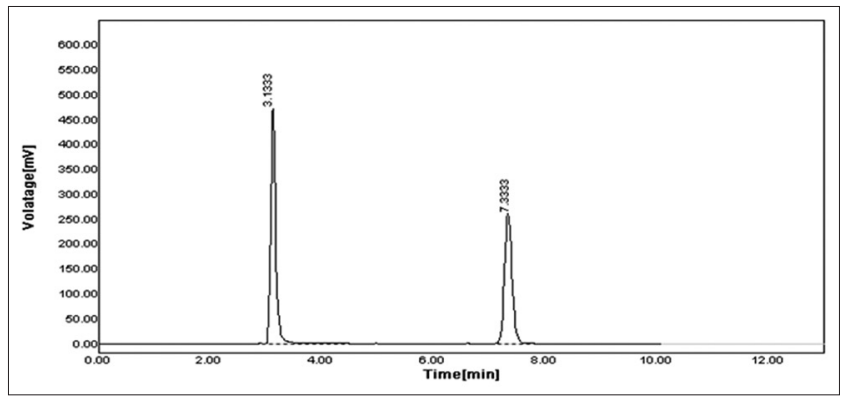

Fig. 14: Chromatogram interday precision 
Table 7: Intra- and interday precision studies on RP-HPLC method for EMB and TEN

\begin{tabular}{|c|c|c|c|c|c|c|}
\hline \multirow[t]{2}{*}{ Method } & \multirow[t]{2}{*}{ Drug } & \multirow[t]{2}{*}{ Concentration $(\mu \mathrm{g} / \mathrm{ml})$} & \multicolumn{2}{|c|}{ Intraday precision } & \multicolumn{2}{|c|}{ Inter-day precision } \\
\hline & & & Mean \pm SD & $\%$ Amount found & Mean \pm SD & $\%$ Amount found \\
\hline \multirow[t]{5}{*}{ RP-HPLC method } & EMB & 20 & $19.74 \pm 21.74$ & 97.77 & $1475.3 \pm 29.75$ & 102.70 \\
\hline & & 40 & $39.26 \pm 26.54$ & 102.8 & $39.30 \pm 38.77$ & 98.25 \\
\hline & TEN & 30 & $145.0 \pm 19.52$ & 97.77 & $142.30 \pm 29.75$ & 99.19 \\
\hline & & 45 & $224.7 \pm 14.80$ & 102.18 & $2245.1 \pm 45.88$ & 101.96 \\
\hline & & 60 & $298.6 \pm 44.18$ & 102.38 & $259.57 \pm 61.58$ & 102.63 \\
\hline
\end{tabular}

Mean of each 3 reading for RP-HPLC method. RP-HPLC: Reversed-phase high performance liquid chromatographic, SD: Standard deviation, EMB: Emtricitabine, TEN: Tenofovir

Table 8: Robustness study of EMB

\begin{tabular}{|c|c|c|c|}
\hline Parameters & Concentration $(\mu \mathrm{g} / \mathrm{ml})$ & Amount of detected (mean \pm SD) & $\%$ RSD \\
\hline Chromatogram of flow change $0.9 \mathrm{ml}$ & 50 & $2544.24 \pm 39.39$ & 1.55 \\
\hline Chromatogram of flow change $1.1 \mathrm{ml}$ & 50 & $2331.6 \pm 21.55$ & 0.92 \\
\hline Chromatogram of composition change $69 \mathrm{ml} \mathrm{MEOH}+21 \mathrm{ml}$ water & 50 & $1113.7 \pm 17.27$ & 1.55 \\
\hline Chromatogram of composition change $71 \mathrm{ml} \mathrm{MEOH}+37 \mathrm{ml}$ water & 50 & $1182 \pm 2002$ & 1.69 \\
\hline Chromatogram of composition change wavelength change $272 \mathrm{~nm}$ & 50 & $3135.9 \pm 33.46$ & 1.07 \\
\hline Chromatogram of composition change wavelength change $274 \mathrm{~nm}$ & 50 & $3016.2 \pm 21.10$ & 0.70 \\
\hline
\end{tabular}

RSD: Relative standard deviation, SD: Standard deviation, EMB: Emtricitabine

Table 9: Robustness study of TEN

\begin{tabular}{|c|c|c|c|}
\hline Parameters & Concentration $(\mu \mathrm{g} / \mathrm{ml})$ & Amount of detected (mean \pm SD) & $\%$ RSD \\
\hline Chromatogram of flow change $0.9 \mathrm{ml}$ & 75 & $3487.84 \pm 30.90$ & 0.89 \\
\hline Chromatogram of flow change $1.1 \mathrm{ml}$ & 75 & $3547.77 \pm 30.24$ & 0.85 \\
\hline Chromatogram of composition change $69 \mathrm{ml} \mathrm{MEOH}+21 \mathrm{ml}$ water & 75 & $1154.7 \pm 12.50$ & 1.08 \\
\hline Chromatogram of composition change $71 \mathrm{ml} \mathrm{MEOH}+37 \mathrm{ml}$ water & 75 & $1282.80 \pm 20.02$ & 1.56 \\
\hline Chromatogram of composition change wavelength change $272 \mathrm{~nm}$ & 75 & $3628.8 \pm 23.31$ & 0.64 \\
\hline Chromatogram of composition change wavelength change $274 \mathrm{~nm}$ & 75 & $3562.41 \pm 51.13$ & 1.44 \\
\hline
\end{tabular}

RSD: Relative standard deviation, SD: Standard deviation, TEN: Tenofovir

Table 10: Repeatability studies on RP-HPLC for EMB and TEN

\begin{tabular}{|c|c|c|c|c|}
\hline Method & Concentration of EMB and TEN (mg/ml) & Peak area & Amount found (mg) & $\%$ Amount found \\
\hline \multirow[t]{7}{*}{ RP-HPLC method for EMB } & 50 & 3054.69 & 49.21 & 98.42 \\
\hline & 50 & 3055.69 & 49.22 & 99.00 \\
\hline & 50 & 3059.70 & 40.23 & 96.00 \\
\hline & 50 & 3058.72 & 50.10 & 101.00 \\
\hline & 50 & 3059.73 & 50.20 & 98.00 \\
\hline & & Mean \pm SD & $49.56 \pm 1.23$ & \\
\hline & & $\%$ RSD & 0.23 & \\
\hline \multirow{6}{*}{ RP-HPLC method for TEN } & 75 & 3662.05 & 76.55 & 100.00 \\
\hline & 75 & 3660.04 & 75.50 & 101.02 \\
\hline & 75 & 3666.01 & 76.49 & 102.96 \\
\hline & 75 & 3659.06 & 75.48 & 101.40 \\
\hline & & Mean \pm SD & $75.20 \pm 2.20$ & \\
\hline & & $\%$ RSD & 0.30 & \\
\hline
\end{tabular}

RSD: Relative standard deviation, SD: Standard deviation, RP-HPLC: Reversed-phase high performance liquid chromatographic, EMB: Emtricitabine, TEN: Tenofovir

between $98 \%$ and $102 \%$ indicates the analytical method that concluded (Table 10).

\section{DISCUSSION}

The proposed method utilize two medium, i.e., methanol + water (acetic acid 0.1\% [OPA]) (70:30\%) v/v) $273 \mathrm{~nm}, 1.0 \mathrm{ml}, \mathrm{pH} 3.0$ gave adequate RT at 3.166 minutes and 7.500 minutes with good peak shape (TP of 4085.3of EMB and 11229.0 of TEN. The values of \% RSD are within the prescribed limit of $2 \%$, showing high precision of methods and recovery was close to $100 \%$ for both the drugs. The comparison of method with already published two methods shows that the developed method is more accurate and economic as compared to other two methods further the method complies with detection of drugs as per their label claim also no further derivatization or modification in spectra is required so the proposed method can be said as simple accurate and economic as compared to other published method.

\section{CONCLUSION}

The developed HPLC methods were found to be more accurate, precise, and reproducible. The analysis of tablets containing two drugs gave the satisfactory results. The statistical parameter of these methods showed good results. The recovery studies revealed excellent accuracy and high precision of the method. The methods were found to be simple and timesaving. All proposed methods could be applied for routine analysis in quality control laboratories. 


\section{ACKNOWLEDGMENTS}

The authors are grateful to Emcure Pvt. Ltd. (Pune, Maharashtra, India) for providing gift samples of EMB and TEN. Authors are also thankful to Management and Principal of Gangamai College of Pharmacy, Nagaon, Dhule, Maharashtra for providing timely support for the research work.

\section{REFERENCES}

1. Martindale A. The Complete Drug Reference. $35^{\text {th }}$ ed. London: Pharmaceutical Press; 2007. p. 811.

2. Indian Pharmacopoeia. Government of India, Ministry of Health and Family Welfare. Vol. II. Ghaziabad: The Indian Pharmacopoeia Commission; 2010. p. 1272-3.

3. The Merck Index. An Encyclopedia of Chemicals, Drugs and Biological. $13^{\text {th }}$ ed., Vol. 630. Merck Research Laboratories; 2007. p. 1631-2.

4. Indian Pharmacopoeia. Government of India, Ministry of Health and Family Welfare. Vol. III. Ghaziabad: The Indian Pharmacopoeia Commission; 2010. p. 2188-93.

5. Gomes NA, Vaidya VV, Pudage A, Joshi SS, Parekh SA. Liquid chromatography-tandem mass spectrometry (LC-MS/MS) method for simultaneous determination of tenofovir and emtricitabine in human plasma and its application to a bioequivalence study. J Pharm Biomed Anal 2008;48(3):918-26
6. D'Avolio A, Sciandra M, Siccardi M, Baietto L, Gonzalez de Requena D, Bonora S, et al. A new assay based on solid-phase extraction procedure with LC-MS to measure plasmatic concentrations of tenofovir and emtricitabine in HIV infected patients. J Chromatogr Sci 2008;46(6):524-8.

7. Sentenac S, Fernandez C, Thrillers A, Lachat P, Aymard G. Sensitive determination of tenofovir in human plasma samples using reverse phase liquid chromatography. J Chromatogr B 2003;793(2):317-24.

8. Delahunty T, Bushman L, Fletcher CV. Sensitive assay for determining plasma tenofovir concentrations by LC/MS/MS. J Chromatogr B Analyt Technol Biomed Life Sci 2006;830(1):6-12.

9. Takahashi M, Kudaka Y, Okumura N, Hirano A, Banno K, Kaneda T. Determination of plasma tenofovir concentrations using a conventional LC-MS method. Biol Pharm Bull 2007;30(9):1784-6.

10. Droste AH, Aarnoutse RE, Burger DM. Determination of emtricitabine in human plasma using HPLC with fluorimetric detection. J Liq Chromatogr Relat Technol 2007;30:2769-78.

11. Reddy GS, Kumar SA, Debnath M, Kumar VR. Analytical method development and validation for simultaneous determination of dutasteride and tamsulosin in bulk as well as in pharmaceutical dosage form by using RP-HPLC. Int J Pharm Pharm Sci 2014;6(3):77-84

12. Patel MM, Patel HD. Development and validation of RP-HPLC method for simultaneous estimation of terbinafine hydrochloride and mometasone furoate in combined dosage form. Int $\mathrm{J}$ Pharm Pharm Sci 2014;6(1):106-9. 